\title{
The Impact of Changes in InFeed Rate on Surface Integrity after Chrome Plate Grinding by Silicon Carbide
}

Martin Marek, Martin Novák, Karel Šramhauser

Faculty of Mechanical Engineering, J. E. Purkyně University in Usti nad Labem, Pasteurova 3334/7, 400 01 Ústí nad Labem. Email: martin.marek@ujep.cz,martin.novak1@ujep.cz, karel.sramhauser@ujep.cz

Grinding is a significant and very commonly used technology, allowing for important gains in surface integrity. The surface integrity quality after grinding is one of the most important parameters, which is prescribed on the production drawing. Chrome plating as protection against corrosion, erosion, abrasion and as a material for the overhaul of worn-out parts is used. This paper discusses the change of cutting conditions when samples were ground. The surface of all samples was preserved with galvanically applied chrome. The values show which grade of surface roughness is attained when selecting different cutting conditions. The results of surface integrity after grinding were evaluated depending on the comparison of the parameters of roughness. The input parameters of cutting conditions were chosen based on the experience, which was implemented.

Keywords: grinding, hard chrome plate, surface integrity, cutting conditions

\section{Introduction}

The grinding is a finishing operation, where using abrasive wheels, which is a compound of abrasive grains. These grains are bonded in a matrix. The grinding is a cutting process, where cutting edges are irregularly shaped and randomly spaced. Due to the randomly shaped and irregularly shaped grains, the grinding process is characterized by large amounts of heat, high values of cutting speeds, irregular cutting geometry, irregular removal of chips, a self-sharpening grinding wheel and a small crosssection of the chips. Figure 1 shows how abrasive grains are removing material from the workpiece. $[1,2,3,11$, $12,13]$

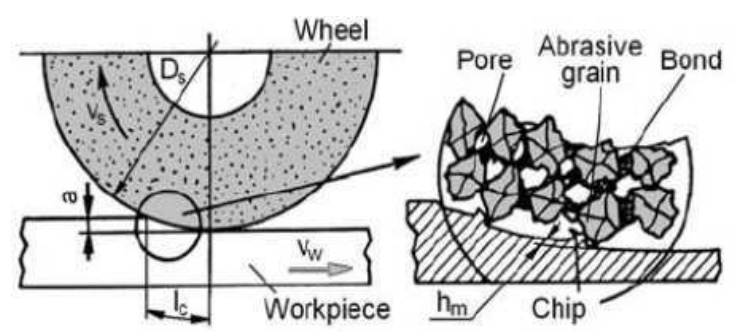

Fig. 1 Mechanism of grinding process [12]

The integrity of the surface is derived from surface roughness and its profile, geometric accuracy, the hardness of the surface and the surface layer, the residual stress, changes of microstructure, thermal changes burn-offs and cracks. The integrity of the surface is a set of all properties which define a new surface. The surface integrity is evaluated and measured according to CSN EN ISO standards. [4, 5, 6, 14]

Hard chrome plating is based on galvanic coating and is a widely used technology in manufacturing. Hard chrome plating is an electrochemical process during which a layer of chromium is applied to the base material.
It is used to reduce wear and increase the life of parts, tools and gauges. Excluded chromium coating has a hardness of 800 to $1200 \mathrm{HV}$. The thickness of the chromium coating ranges is from 5 microns up to about $1 \mathrm{~mm}$. One of the benefits of hard chrome plating is an option to apply layers and is therefore often used for renovation of worn parts. $[7,8,9,10]$

The purpose of this research was to compare the used $\mathrm{SiC}$ (silicon carbon) grinding wheel when grinding the galvanically applied chrome coating after changing cutting conditions. This experiment was in cooperation with Solar Turbines EAME L.t.d. The main consideration in measurement and evaluation was choosing components of surface integrity - the roughness of the surface and its profile and circularity.

\section{Plan of experiment}

The aim of the experiment was grinding samples, which are shown in Fig. 2, where the base material was chromic-molybdate steel (shaft), which corresponds with AMS 6415 standards and the coating material was Chrom (Cr).
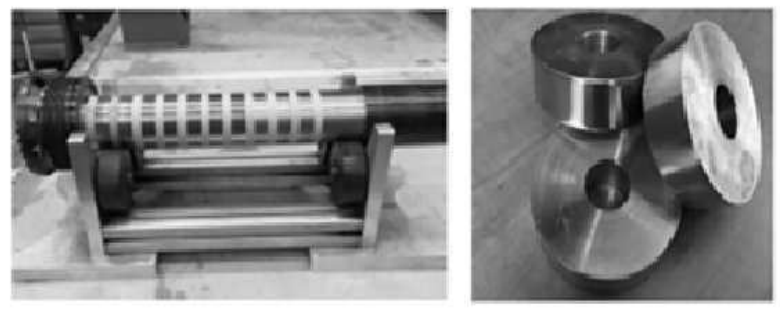

Fig. 2 Example of pattern

On the outer surface of the samples a galvanic chrom coating which had $0.390 \mathrm{~mm}$ thickness was applied. Fig. 3 show 10x measurements of chrome plated layer. 


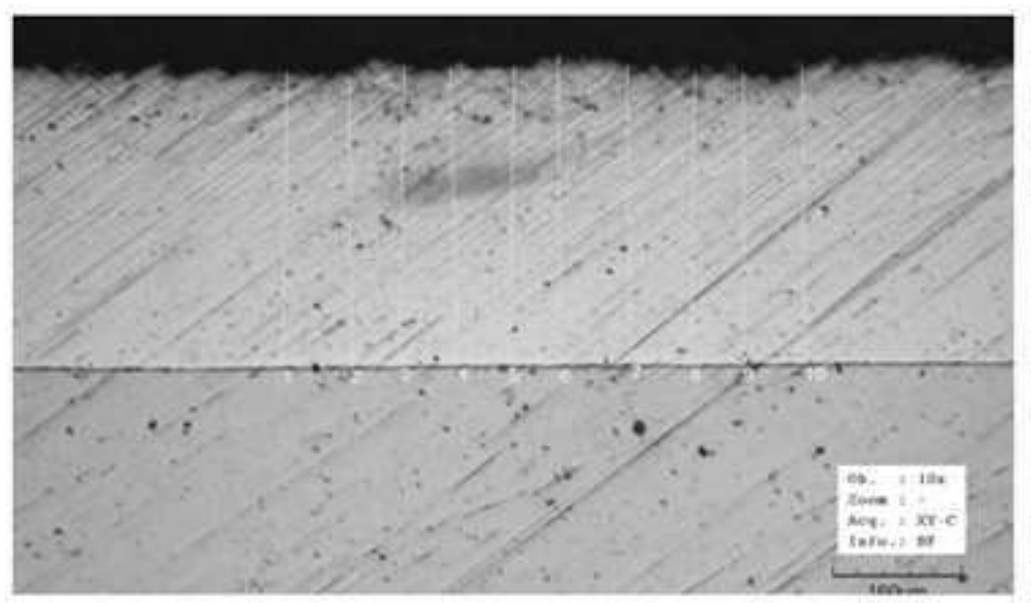

\begin{tabular}{|c|c|}
\cline { 2 - 2 } \multicolumn{1}{c|}{} & Lenght $[\mu \mathrm{m}]$ \\
\hline 1 & 390.05 \\
\hline 2 & 385.01 \\
\hline 3 & 395.05 \\
\hline 4 & 392.60 \\
\hline 5 & 393.80 \\
\hline 6 & 410.00 \\
\hline 7 & 392.52 \\
\hline 8 & 388.80 \\
\hline 9 & 383.75 \\
\hline 10 & 390.01 \\
\hline Avarge value & $\mathbf{3 9 2 . 1 6}$ \\
\hline Standartat deviation & $\mathbf{\pm 7 . 2 4}$ \\
\hline
\end{tabular}

Fig. 3 Chrom-plated sample

\section{The cutting conditions}

In the process of grinding, Hakufluid 182 process fluid was chosen, which is specifically for machining. This liquid provides a cooling effect, has excellent lubricating ability, is odorless and improves the roughness of the machined surface. The grinding wheel was C49 150 J9V with a silicon carbide base, characterized by high hardness, moderate grain size, porous structure and a ceramic binder.

The experiment is based on the combination of cutting conditions, which are shown in Tab. 1. In my case, we changed the cutting speed of the grinding wheel from 30 $\mathrm{m} . \mathrm{s}^{-1}$ to $40 \mathrm{~m} \cdot \mathrm{s}^{-1}$ and the infeed rate from $0,13 \mathrm{~mm} . \mathrm{min}-1$ to $0,64 \mathrm{~mm} \cdot \mathrm{min}^{-1}$. For both cutting speeds 5 different infeed rates were chosen. The depth removal rate was 0,05 $\mathrm{mm}$. The grinding was done by grooving manner on a BU16 grinder.

Each sample is named according to table 1, where there is 10 sample "Bx", and each one is subject to certain cutting conditions by which the sample was ground. Each grinding operation was repeated twice on a new sample under the same cutting conditions, $\mathrm{Bx} \_1$ or $\mathrm{Bx} 2$,

Tab. 1 Cutting Condition

\begin{tabular}{|c|c|c|c|c|c|}
\hline \multirow{2}{*}{ Material } & \multirow{2}{*}{ Grinding wheel } & \multicolumn{3}{|c|}{ Cutting conditions } & \multirow{2}{*}{ No. sample } \\
\hline & & $\mathbf{V w}$ & Vc & Vf & \\
\hline \multirow{10}{*}{$\begin{array}{c}\text { Chrome } \\
\text { plate }\end{array}$} & \multirow{10}{*}{ C49 $150 \mathrm{~J} 9 \mathrm{~V}$} & \multirow{10}{*}{$15 \mathrm{~m} \cdot \mathrm{min}^{-1}$} & \multirow{5}{*}{$30 \mathrm{~m} \cdot \mathrm{s}^{-1}$} & $0.13 \mathrm{~mm} \cdot \mathrm{min}^{-1}$ & B1 \\
\hline & & & & $0.17 \mathrm{~mm} \cdot \mathrm{min}^{-1}$ & $\mathrm{~B} 2$ \\
\hline & & & & $0.26 \mathrm{~mm} \cdot \mathrm{min}^{-1}$ & B3 \\
\hline & & & & $0.41 \mathrm{~mm} \cdot \mathrm{min}^{-1}$ & B4 \\
\hline & & & & $0.64 \mathrm{~mm} \cdot \mathrm{min}^{-1}$ & B5 \\
\hline & & & \multirow{5}{*}{$40 \mathrm{~m} \cdot \mathrm{s}^{-1}$} & $0.13 \mathrm{~mm} \cdot \mathrm{min}^{-1}$ & B6 \\
\hline & & & & $0.17 \mathrm{~mm} \cdot \mathrm{min}^{-1}$ & B7 \\
\hline & & & & $0.26 \mathrm{~mm} \cdot \mathrm{min}^{-1}$ & B8 \\
\hline & & & & $0.41 \mathrm{~mm} \cdot \mathrm{min}^{-1}$ & B9 \\
\hline & & & & $0.64 \mathrm{~mm} \cdot \mathrm{min}^{-1}$ & $\mathrm{~B} 10$ \\
\hline
\end{tabular}

\section{Surface roughness and profile and circularity using $\mathrm{SiC}$ grinding wheel}

I was dealing with the measurement of surface roughness, where I was following Ra, Rt, Rz, Rq, Rmax, Rvk and Rpk parameters. Also, I was focusing on circularity which is marked ,E,.. For the measurement of the surface roughness a Profilometr Hommel Tester T8000 device (Fig. 4) was used and for the measurement of circularity a Hommel Tester Form T4004 device (Fig. 5) was used. Measurement of surface roughness was performed 12 times at $30^{\circ}$ and measurement of circularity was conducted at 3 specific points from the outer diameter. Arithmetic mean and standard deviation was calculated from the measurement of roughness and circularity. The results of surface roughness and circularity are shown in Tab. 2 and Tab.3.

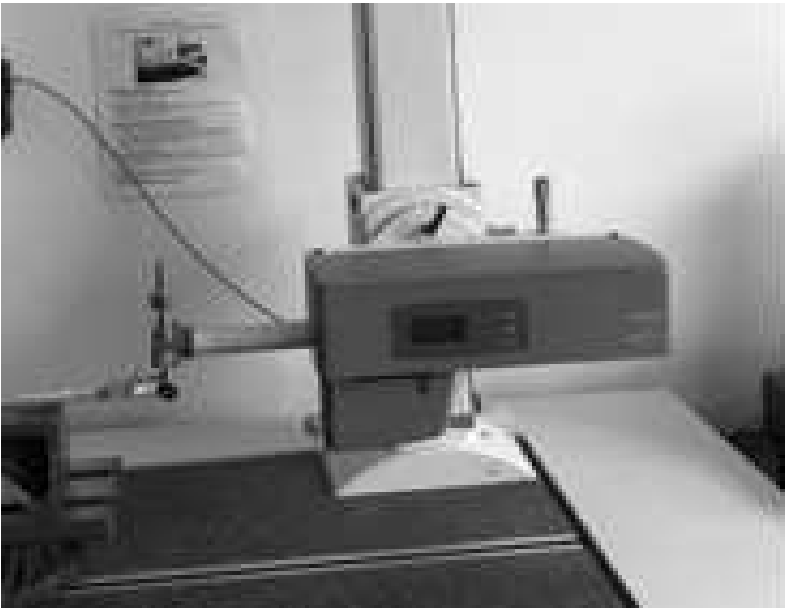

Fig. 4 Profilometr Hommel Tester T8000 
Tab. 2 Average Values of Surface Roughness

\begin{tabular}{|c|c|c|c|c|c|c|c|c|}
\hline $\begin{array}{c}\text { No } \\
\text { sample } \\
\end{array}$ & & $\begin{array}{c}\mathbf{R a} \\
{[\boldsymbol{\mu m}]}\end{array}$ & $\begin{array}{c}\mathbf{R z} \\
{[\mu \mathrm{m}]}\end{array}$ & $\begin{array}{c}\mathbf{R t} \\
{[\mu \mathrm{m}]}\end{array}$ & $\begin{array}{c}\operatorname{Rmax} \\
{[\mu \mathrm{m}]}\end{array}$ & $\begin{array}{c}\text { Rpk } \\
{[\mu \mathrm{m}]} \\
\end{array}$ & $\begin{array}{c}\text { Rvk } \\
{[\mu \mathrm{m}]}\end{array}$ & $\begin{array}{c}\mathbf{R q} \\
{[\mu \mathrm{m}]}\end{array}$ \\
\hline \multirow{2}{*}{ B1_1 } & Arithmetic Average & 0.194 & 1.418 & 1.730 & 1.664 & 0.213 & 0.335 & 0.245 \\
\hline & Standart Deviation & 0.007 & 0.061 & 0.138 & 0.163 & 0.024 & 0.026 & 0.009 \\
\hline \multirow{2}{*}{ B1_2 } & Arithmetic Average & 0.176 & 1.287 & 1.618 & 1.537 & 0.198 & 0.267 & 0.220 \\
\hline & Standart Deviation & 0.011 & 0.085 & 0.248 & 0.231 & 0.018 & 0.020 & 0.013 \\
\hline \multirow{2}{*}{ B2_1 } & Arithmetic Average & 0.236 & 1.657 & 2.077 & 2.037 & 0.271 & 0.346 & 0.296 \\
\hline & Standart Deviation & 0.010 & 0.096 & 0.209 & 0.173 & 0.029 & 0.028 & 0.013 \\
\hline \multirow{2}{*}{ B2_2 } & Arithmetic Average & 0.238 & 1.603 & 1.963 & 1.920 & 0.258 & 0.313 & 0.295 \\
\hline & Standart Deviation & 0.007 & 0.071 & 0.198 & 0.229 & 0.023 & 0.046 & 0.008 \\
\hline \multirow{2}{*}{ B3_1 } & Arithmetic Average & 0.258 & 1.791 & 2.273 & 2.138 & 0.275 & 0.378 & 0.323 \\
\hline & Standart Deviation & 0.006 & 0.056 & 0.182 & 0.140 & 0.048 & 0.033 & 0.008 \\
\hline \multirow{2}{*}{ B3_2 } & Arithmetic Average & 0.274 & 1.939 & 2.363 & 2.218 & 0.339 & 0.371 & 0.344 \\
\hline & Standart Deviation & 0.007 & 0.116 & 0.231 & 0.169 & 0.018 & 0.025 & 0.008 \\
\hline \multirow{2}{*}{ B4_1 } & Arithmetic Average & 0.297 & 2.050 & 2.520 & 2.382 & 0.334 & 0.427 & 0.373 \\
\hline & Standart Deviation & 0.011 & 0.165 & 0.351 & 0.215 & 0.046 & 0.056 & 0.016 \\
\hline \multirow{2}{*}{ B4_2 } & Arithmetic Average & 0.297 & 2.187 & 2.641 & 2.503 & 0.363 & 0.486 & 0.378 \\
\hline & Standart Deviation & 0.010 & 0.125 & 0.262 & 0.229 & 0.051 & 0.052 & 0.015 \\
\hline \multirow{2}{*}{ B5_1 } & Arithmetic Average & 0.337 & 2.392 & 2.943 & 2.825 & 0.401 & 0.519 & 0.424 \\
\hline & Standart Deviation & 0.015 & 0.132 & 0.225 & 0.169 & 0.031 & 0.045 & 0.017 \\
\hline \multirow{2}{*}{ B5_2 } & Arithmetic Average & 0.331 & 2.368 & 2.864 & 2.731 & 0.400 & 0.506 & 0.417 \\
\hline & Standart Deviation & 0.010 & 0.135 & 0.244 & 0.206 & 0.043 & 0.062 & 0.014 \\
\hline \multirow{2}{*}{ B6_1 } & Arithmetic Average & 0.271 & 1.811 & 2.152 & 2.077 & 0.262 & 0.417 & 0.336 \\
\hline & Standart Deviation & 0.009 & 0.086 & 0.230 & 0.173 & 0.026 & 0.046 & 0.011 \\
\hline \multirow{2}{*}{ B6_2 } & Arithmetic Average & 0.268 & 1.952 & 2.387 & 2.297 & 0.307 & 0.440 & 0.339 \\
\hline & Standart Deviation & 0.015 & 0.183 & 0.259 & 0.231 & 0.031 & 0.073 & 0.020 \\
\hline \multirow{2}{*}{ B7_1 } & Arithmetic Average & 0.292 & 2.021 & 2.435 & 2.297 & 0.341 & 0.379 & 0.365 \\
\hline & Standart Deviation & 0.008 & 0.124 & 0.306 & 0.320 & 0.039 & 0.045 & 0.012 \\
\hline \multirow{2}{*}{ B7_2 } & Arithmetic Average & 0.298 & 2.075 & 2.486 & 2.395 & 0.322 & 0.543 & 0.377 \\
\hline & Standart Deviation & 0.008 & 0.092 & 0.163 & 0.144 & 0.020 & 0.052 & 0.009 \\
\hline \multirow{2}{*}{ B8_1 } & Arithmetic Average & 0.301 & 1.986 & 2.354 & 2.255 & 0.321 & 0.487 & 0.377 \\
\hline & Standart Deviation & 0.011 & 0.090 & 0.127 & 0.157 & 0.034 & 0.076 & 0.013 \\
\hline \multirow{2}{*}{ B8_2 } & Arithmetic Average & 0.304 & 2.143 & 2.584 & 2.505 & 0.376 & 0.432 & 0.383 \\
\hline & Standart Deviation & 0.006 & 0.080 & 0.235 & 0.223 & 0.042 & 0.025 & 0.007 \\
\hline \multirow{2}{*}{ B9_1 } & Arithmetic Average & 0.323 & 2.167 & 2.598 & 2.475 & 0.289 & 0.524 & 0.402 \\
\hline & Standart Deviation & 0.008 & 0.115 & 0.227 & 0.166 & 0.032 & 0.061 & 0.009 \\
\hline \multirow{2}{*}{ B9_2 } & Arithmetic Average & 0.315 & 2.401 & 3.099 & 2.920 & 0.384 & 0.555 & 0.402 \\
\hline & Standart Deviation & 0.020 & 0.130 & 0.292 & 0.296 & 0.054 & 0.079 & 0.027 \\
\hline \multirow{2}{*}{ B10_1 } & Arithmetic Average & 0.361 & 2.517 & 2.997 & 2.877 & 0.443 & 0.533 & 0.453 \\
\hline & Standart Deviation & 0.011 & 0.127 & 0.190 & 0.235 & 0.035 & 0.051 & 0.014 \\
\hline \multirow{2}{*}{ B10_2 } & Arithmetic Average & 0.363 & 2.481 & 3.140 & 3.079 & 0.385 & 0.552 & 0.454 \\
\hline & Standart Deviation & 0.015 & 0.148 & 0.365 & 0.400 & 0.043 & 0.105 & 0.019 \\
\hline
\end{tabular}

Tab. 3 Average Values of Circularity $E$

\begin{tabular}{|c|c|c|c|c|c|c|c|c|c|c|}
\cline { 2 - 10 } \multicolumn{1}{c|}{} & B1_1 & B2_1 & B3_1 & B4_1 & B5_1 & B6_1 & B7_1 & B8_1 & B9_1 & B10_1 \\
\hline Arithmetic Average & 1.037 & 1.363 & 1.890 & 2.737 & 5.467 & 1.380 & 1.947 & 2.140 & 2.740 & 4.760 \\
\hline Standart Deviation & 0.214 & 0.057 & 0.255 & 0.015 & 0.185 & 0.105 & 0.323 & 0.281 & 0.200 & 0.560 \\
\hline & B1_2 & B2_2 & B3_2 & B4_2 & B5_2 & B6_2 & B7_2 & B8_2 & B9_2 & B10_2 \\
\hline Arithmetic Average & 1.227 & 1.837 & 1.907 & 2.287 & 4.793 & 1.390 & 1.780 & 2.097 & 3.733 & 4.717 \\
\hline Standart Deviation & 0.285 & 0.163 & 0.158 & 0.386 & 0.573 & 0.036 & 0.010 & 0.121 & 0.072 & 0.138 \\
\hline
\end{tabular}




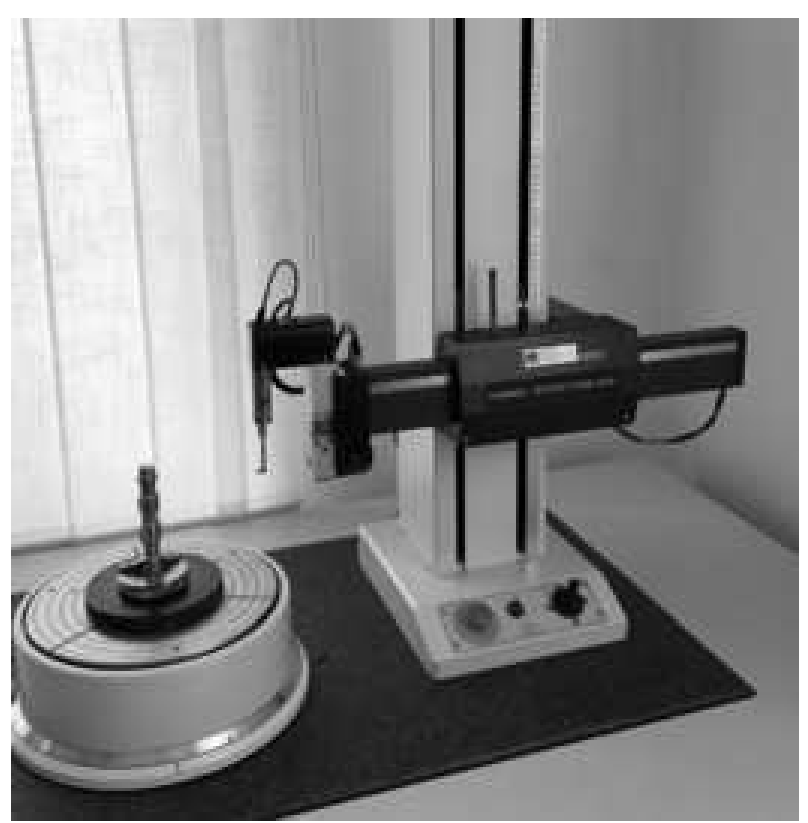

Fig. 5 Device for measuring od circularity - Hommel Tester Form T4004

\subsection{Average arithmetic deviation analysis - Ra}

In the ensuing graph is described the dependence of the roughness $\mathrm{Ra}$ on the infeed rate. The light blue and light green show the first grinding. The dark blue and dark green show the second grinding to verify the grinding process. When focusing on the graph, it can be seen that the second grinding process confirms the values of the $\mathrm{Ra}$ parameter during the first grinding process. By growing the infeed rate of the grinding wheel $(0.13 ; 0.17 ; 0.26$; $0.41 ; 0.64)$, it was clearly visible that there was an increased roughness of the surface. The lowest value $0.176 \mu \mathrm{m}$ was achieved with a cutting speed of $40 \mathrm{~m} \cdot \mathrm{s}^{-1}$ and infeed rate of $0.13 \mathrm{~mm} \cdot \mathrm{min}^{-1}$. The highest value $0.363 \mu \mathrm{m}$ was achieved using a cutting speed of $40 \mathrm{~m} \cdot \mathrm{s}^{-1}$ and infeed rate of $0.64 \mathrm{~mm} \cdot \mathrm{min}^{-1}$. The second grinding with different infeed rates, the same surface roughness values were achieved. In the graph is seen a value of reliability called $\mathrm{R}^{2}$. This value for parameter Ra where the cutting speed was $30 \mathrm{~m} . \mathrm{s}^{-1}$ is 0.9938 and when the cutting speed was $40 \mathrm{~m} . \mathrm{s}^{-}$ ${ }^{1}$ is 0.9824 . That means reliability of $99.3 \%$ and $98.2 \%$.

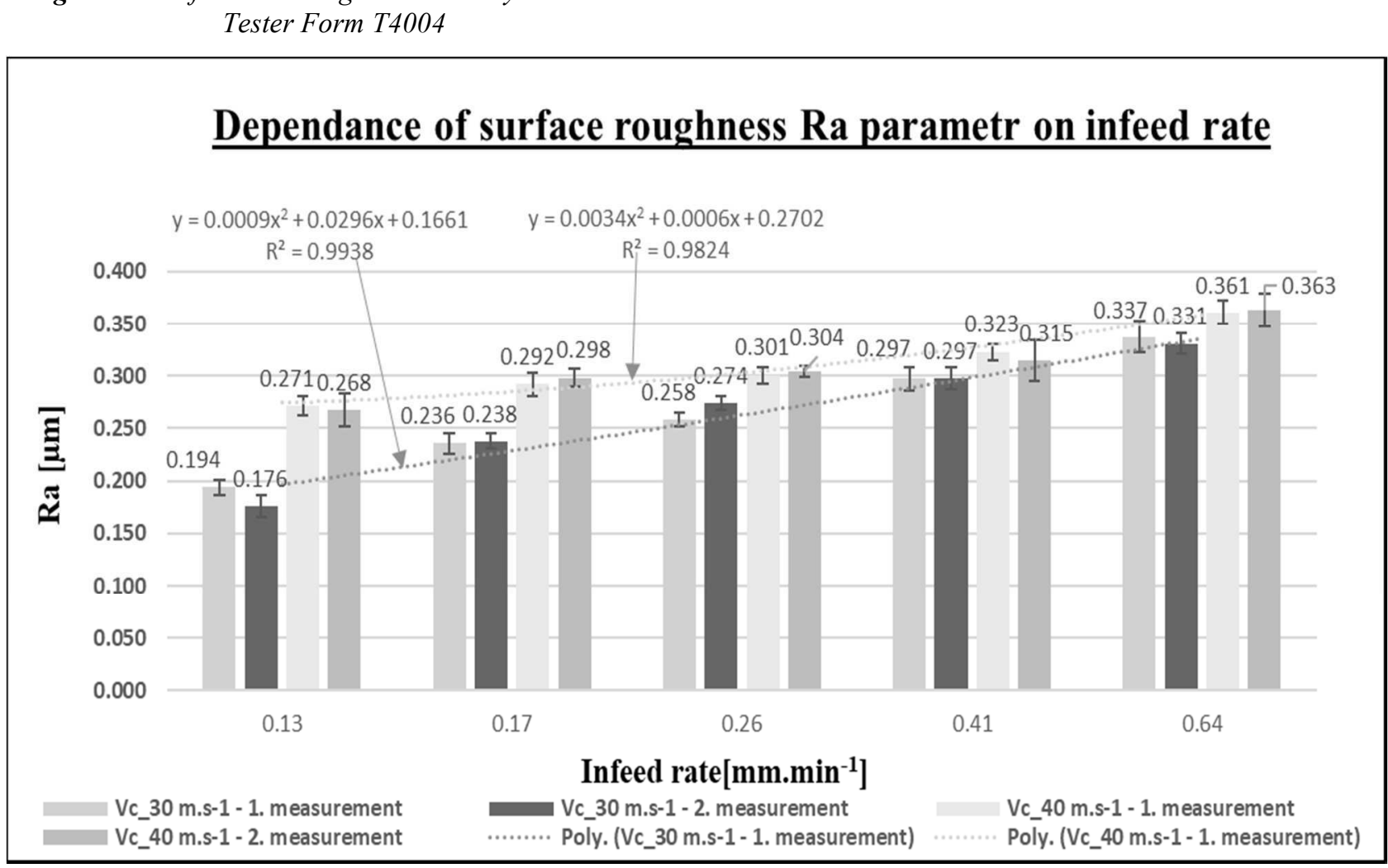

Fig. 6 The average value $\mathrm{Ra}$

\subsection{Average arithmetic deviation analysis - $\mathbf{R z}$}

The graph in Fig 7. has similar dependence as parameter Ra. The parameter $\mathrm{Rz}$ is typical for the minimum and maximum height of valleys in the measured length. The lowest value $1.287 \mu \mathrm{m}$ was achieved using a cutting speed of $40 \mathrm{~m} . \mathrm{s}^{-1}$ and infeed rate of $0.13 \mathrm{~mm} . \mathrm{min}^{-1}$ (samle
B6). The highest value $2.517 \mu \mathrm{m}$ was achieved with a cutting speed of $30 \mathrm{~m} . \mathrm{s}^{-1}$ and infeed rate of $0.64 \mathrm{~mm} . \mathrm{min}^{-}$ 1 (samle B5). With increasing infeed rate and cutting speed, the roughness values are higher. From a reliability point of view, values are very reliable, $99.1 \%$ and $92.6 \%$. Lower reliability for cutting speed $40 \mathrm{~m} . \mathrm{s}^{-1}$ caused a slight value decrease in infeed rate of $0.26 \mathrm{~mm} . \mathrm{min}^{-1}$ 


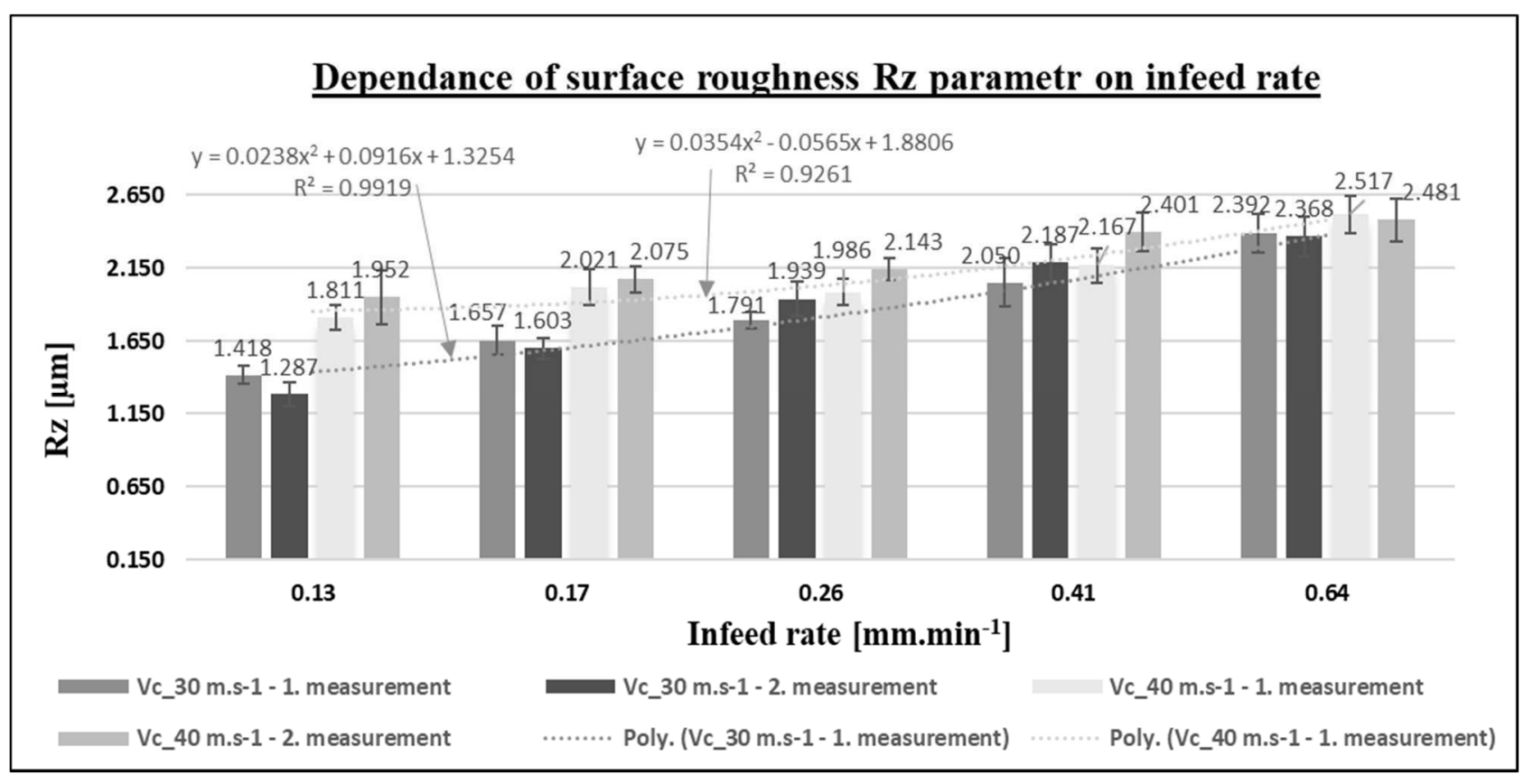

Fig. 7 The average value $R z$

\subsection{Average arithmetic deviation analysis - Rt}

The Rt parameter represents the maximum height of the profile in surface rougness. Like previous graphs, this graph shows a relationship of $\mathrm{Rz}$ parameter and increa- sing the infeed rate speed of the grinding wheel. Each value is supplemented by standard deviation, where the values are in tab. 2 and results are around $10 \%$. For example, sample B7 $12.297 \pm 0.320 \mu \mathrm{m}$ was achived. At the lowest infeed rate and highest infeed rate, the values increased by almost $58 \%$.

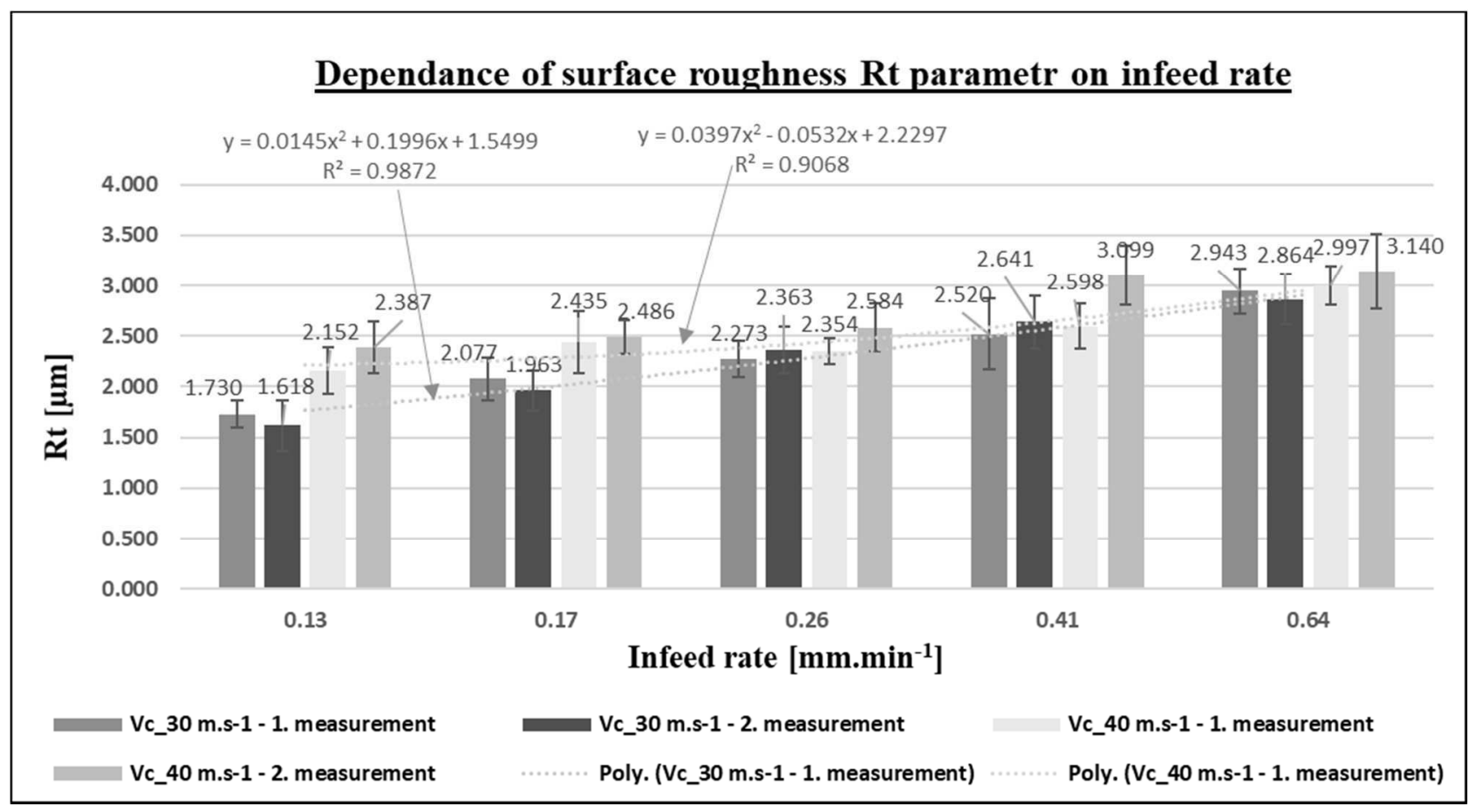

Fig. 8 The average value $R t$

\subsection{Average arithmetic deviation analysis - Rpk and} Rvk

The parameters Rpk and Rvk express the highest peak and highest valley. The next graph on figure 9 are values of parameter Rpk and Rvk. These values are only for cutting speeds of $30 \mathrm{~m} \cdot \mathrm{s}^{-1}$ and $40 \mathrm{~m} \cdot \mathrm{s}^{-1}$ and the corresponding infeed rate per Table 1. In the graph on Figure 9 it can be seen the surface has bigger valleys than peaks. By increasing the infeed rate, the values are increased. It can be 
said that all infeed rates result in valleys that are $50-75 \%$ larger than the peaks. All values of peaks and valleys were increased. Only using a cutting speed of $40 \mathrm{~m} \cdot \mathrm{s}^{-1}$ decreased the peaks, but the final infeed rate increased again as the other values.

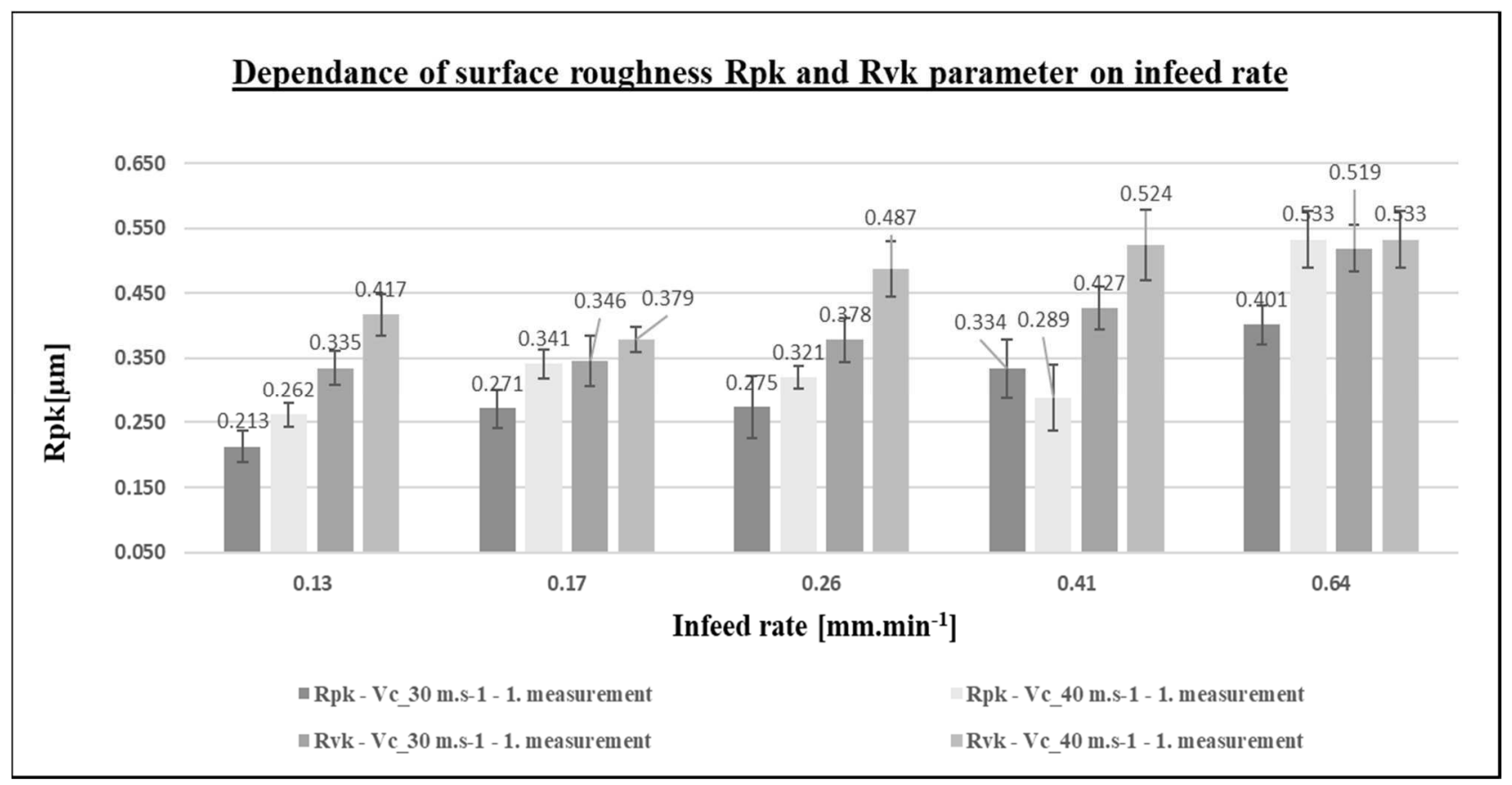

Fig. 9 The average value Rpk and Rvk

\subsection{Analysis of surface profile - Material ratio curve}

The uniqueness of the surface is given by the tool, the cutting conditions and the technology. For each technology, the surface profile is a set of specific properties. Figures 10 and 11 show the graphs and the material share of the surface. Figure 10 shows a cutting speed of $30 \mathrm{~m} \cdot \mathrm{s}^{-}$ ${ }^{1}$ and Figure 11 shows a cutting speed of $40 \mathrm{~m} \cdot \mathrm{s}^{-1}$ with the corresponding infeed rates as shown in Table 1. Looking at the first figure, it is seen that the blue-colored part occupies rather the projections on the surface. With increasing infeed speed, the peaks decrease, although their values increase according to Table 2 (parmeter Rpk, Rvk). Figure 11 shows an even lower profile of the surface, i.e. rather valleys in the material profile. The surface profile with an increasing feed rate has an almost steady shape.

\section{B1 - $30 \mathrm{~m} \cdot \mathrm{s}^{-1}-0.13 \mathrm{~m} \cdot \mathrm{min}^{-1}$}

B3 - $30 \mathrm{~m} \cdot \mathrm{s}^{-1}$ - $0.26 \mathrm{~m} \cdot \mathrm{min}^{-1}$

B5 - $30 \mathrm{~m} . \mathrm{s}^{-1}$ - $0.64 \mathrm{~m} . \mathrm{min}^{-1}$
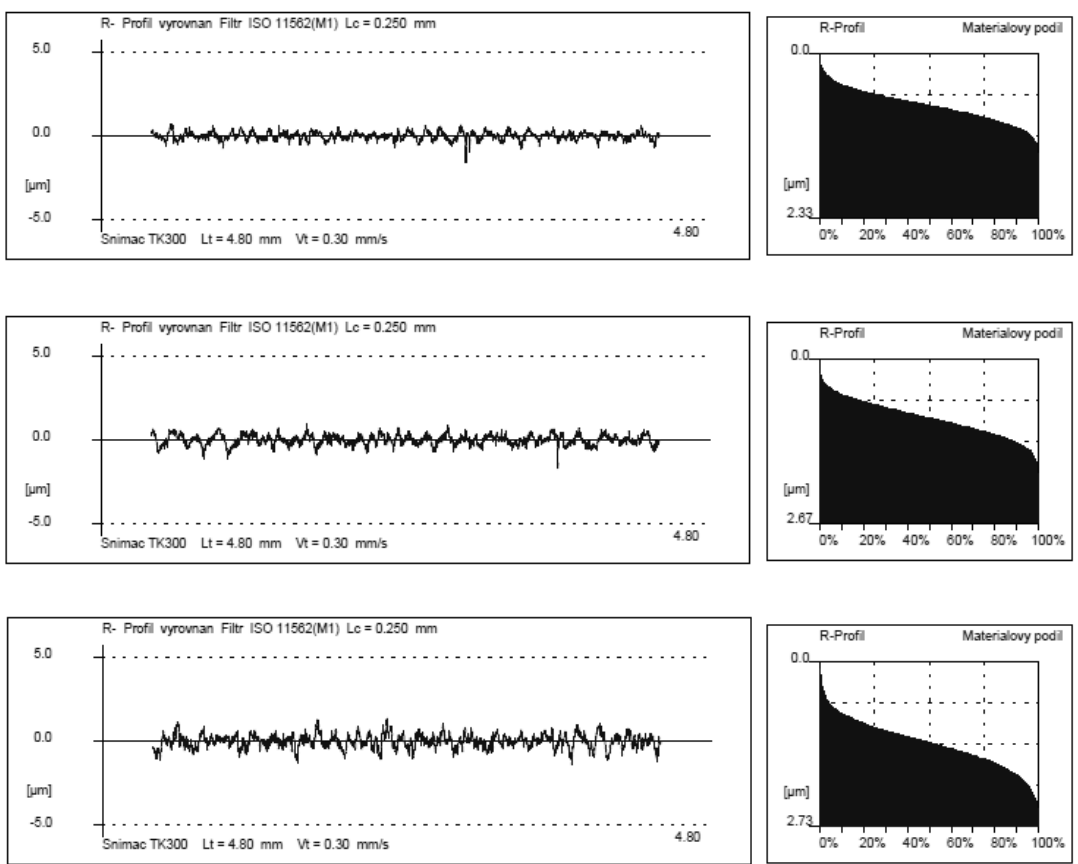

Fig. 10 The surface profile $30 \mathrm{~m} \cdot \mathrm{s}^{-1}$ 
B6 - $40 \mathrm{~m} . \mathrm{s}^{-1}$ - $0.13 \mathrm{~m} \cdot \mathrm{min}^{-1}$
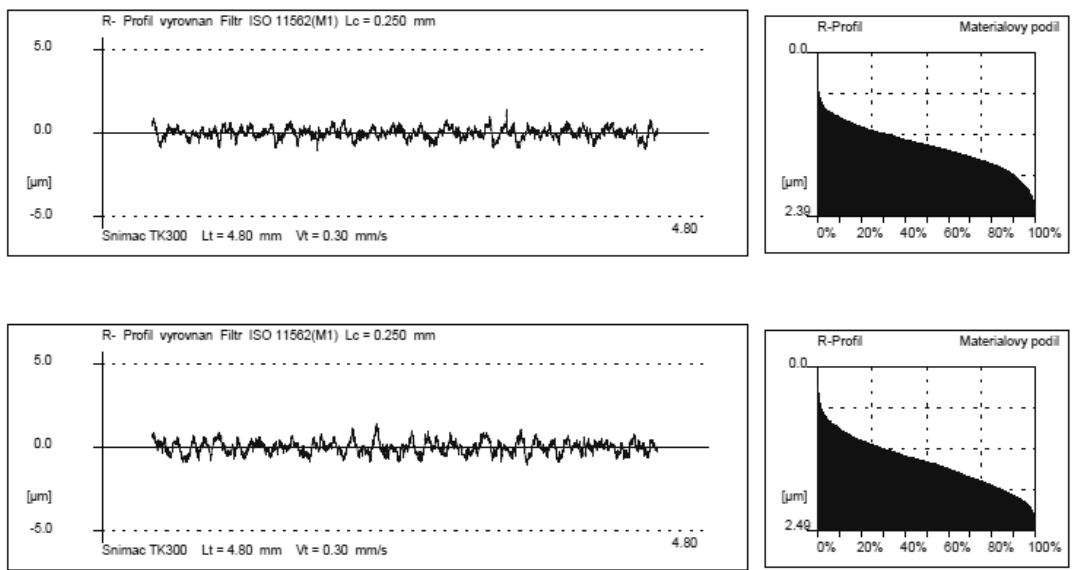

B8 - $40 \mathrm{~m} . \mathrm{s}^{-1}-0.26 \mathrm{~m} \cdot \mathrm{min}^{-1}$
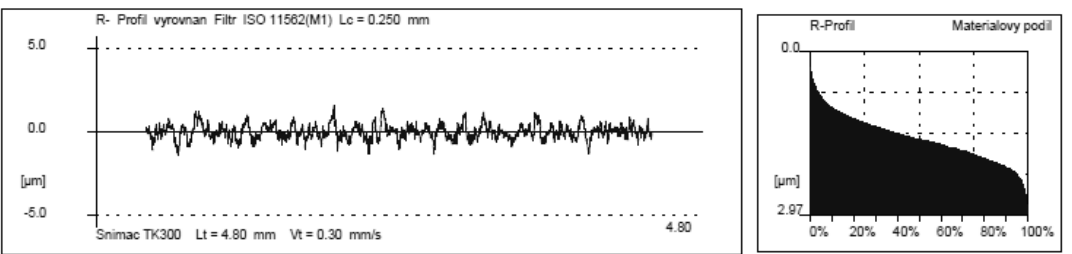

B10 - $40 \mathrm{~m} \cdot \mathrm{s}^{-1}$ - $0.64 \mathrm{~m} \cdot \mathrm{min}^{-1}$

Fig. 11 The surface profile $40 \mathrm{~m} \cdot \mathrm{s}^{-1}$

\subsection{Analysis of circularity}

Figure 12 shows the circularity values that are complemented by a standard deviation. The values can also be read from Table 3. It can be seen from the chart that the greatest deviations are at a cutting speed of 30 and 40 $\mathrm{m} . \mathrm{s}^{-1}$ with a feed rate of $0.64 \mathrm{~mm} \cdot \mathrm{min}^{-1}$. For the feed rate, $0.17 \mathrm{~mm} . \mathrm{min}^{-1}$ and $0.26 \mathrm{~mm} \cdot \mathrm{min}^{-1}$ the values are at the same level. From the point of view of the accuracy of production, the values show good results.

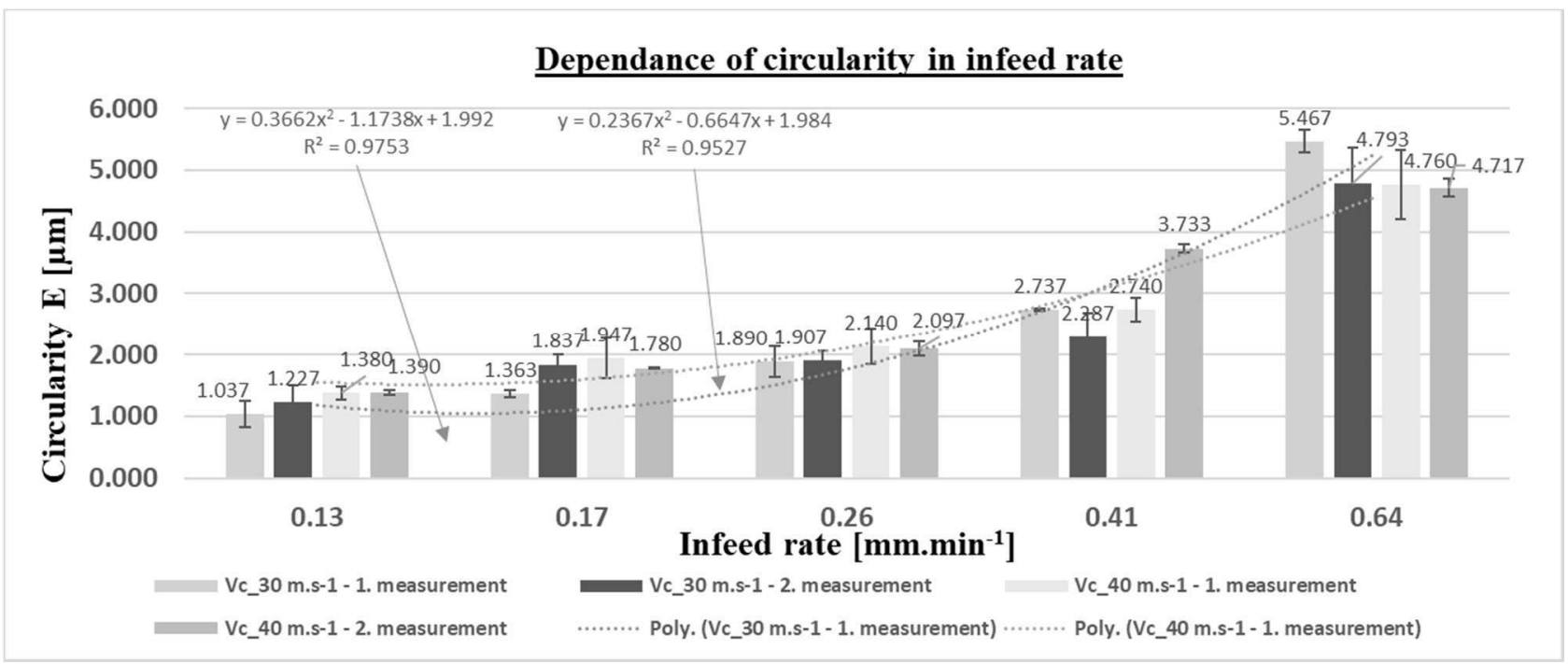

Fig. 12 Dependance of circularity in infeed rate

\section{Summary}

For this experiment 20 samples were tested, where 10 samples were used for the first measurement and the second 10 samples for repeated cycles under the same cutting conditions. All paramaters for this experiment were set to indicate the dependence of changing the cutting conditions on surface roughness and circularity.

Surface roughness at a cutting speed of $30 \mathrm{~m} \cdot \mathrm{s}^{-1}$ and infeed rate of $0.13 \mathrm{~m} \cdot \mathrm{min}^{-1}$ achieved $\mathrm{Ra} 0.194 \pm 0.007$ $\mu \mathrm{m}$. When changing the infeed rate to the highest value which was $0.64 \mathrm{~m} . \mathrm{min}^{-1} \mathrm{Ra} 0.337 \pm 0.015 \mu \mathrm{m}$ was achieved. When changing the infeed rate and the same cutting speed, the increase was approximately $42 \%$. Surface roughness at a cutting speed of $40 \mathrm{~m} \cdot \mathrm{s}^{-1}$ and infeed rate of $0.13 \mathrm{~m} \cdot \mathrm{min}^{-1} \mathrm{Ra} 0.271 \pm 0.009 \mu \mathrm{m}$ was reached. When changing the infeed rate to the highest values, the value of $0.64 \mathrm{~m} . \mathrm{min}^{-1}$ was achieved $\mathrm{Ra} 0.361 \pm 0.11 \mu \mathrm{m}$. When changing the feed rate and the same cutting speed, the increase was approximately $25 \%$. Looking at standard deviations shows accurate values were achived.

The material ratio curve is good in looking at possible 
peaks and valleys in the profile of material. By maintaining a cutting speed of $30 \mathrm{~m} . \mathrm{s}^{-1}$ and increasing infeed rate results in decreasing the region of the profile, with decreasing peaks in the surface profile.

\section{Acknowledgement}

This project was supported by company Solar Turbines EAME Ltd., and under project UJEP-SGS-2017-48002-2 'SGS'.

\section{References}

[1] MASLOV, J., N. (1979). Teorie broušení kovi̊. Praha: SNTL - Nakladatelství technické literatury, n. p., 1979. 244-248 s.

[2] MÁDL, J., KAFKA, J., VRABEC, M., DVOŘÁK, R. (2000). Technologie obrábění, 3. díl. Praha: ČVUT, 2000. 81 s.

[3] G. E. DIETER (1989). Mechanical Metallurgy, McGraw Hill Higher Education, 1989.

[4] MAREK, M., NOVÁK, M., HOLESOVSKY, F., DURAKBASA, M., N. (2017). The Effect of Changes to Nickel Coating Machine on Surface Integrity and Microstructure after Grinding, In: Manufacturing Technology, Vol. 17, No. 6 (2017) pp 906-912, ISSN: 1213-2489.

[5] NOVAK, M., NAPRSTKOVA, N. (2015). Grinding of the Alloy INCONEL 718 and Final oughness of the Surface and Material Share. In: Manufacturing Technology, Vol. 15, No. 6 (2015) pp 1015-1023, ISSN: 1213-2489.

[6] MAREK, M., NOVÁK, M. (2017). The Effect of Changes in Feed Rate on Surface Integrity during Nickel Coating Grinding, Solid State Phenomena, Vol. 261, pp. 207-214, 2017

[7] MAREK, M., NOVÁK, M, SRAMHAUSER, K., SVOBODOVA, J. (2018). Analysis of the base material and hard chrome plated layer in an unloaded state, In: Manufacturing Technology, Vol. 18, No. 4 (2018) pp 616-620, ISSN: 1213-2489.

[8] MALLORY, G. O. a J. B. HAJDU. (1990). Electroless Plating - Fundamentals and Applications. Orlando: William Andrew Publishing/Noyes, 1990, 575 s. ISBN 978-0815512776.

[9] KRAUS, V. (2000). Povrchy a jejich úpravy. Plzeň: Západočeská univerzita v Plzni, 2000. ISBN 80-7082-668-1.

[10] JINFENG ZHANG, CHAO FENG, YUNHUI MA, WEI TANG, SHUAI WANG, XIN ZHONG. (2017). Nondestructive analysis of surface integrity in turning and grinding operations In: Manufacturing Technology, Vol. 17, No. 3, pp. 412-418, ISSN:1213-2489.

[11] OBR, L. Funkční chromování - HEEF 25. Povrchové úpravy. 2008, č. 2. Dostupné z: http://www.povrchoveupravy.cz/2008-02-clanek04.html

[12] GOSTIMIROVIĆ, MARIN \& RODIC, DRAGAN \& KOVAC, PAVEL \& JEŠIĆ, DIŠAN \& KULUNDŽIĆ, NENAD. (2015). Investigation of the cutting forces in creep-feed surface grinding proces. Journal of Production Engineering. 18. 21-24.

[13] C. YAO, Q. JIN, X. HUANG, D. WU, J. REN AND D. ZHANG, "Research on surface integrity of grinding Inconel 718," Int $J$ Adv Manuf REFERENCES | 68 Technol, vol. 65, pp. 10191030, 2013.

[14] Tvrdé chromování. BOMEX CZ. Bomex [online]. 1999 [cit. 2012-04-18]. Dostupné Z: http://www.bomex.cz/cz/3-technologie/8-tvrdechromovani.html 